\section{Daily Light Integral Influences Steviol Glycoside Biosynthesis and Relative Abundance of Specific Glycosides in Stevia}

\author{
Jennifer M. Evans, Veronica A. Vallejo, Randolph M. Beaudry, \\ and Ryan M. Warner ${ }^{1}$ \\ Department of Horticulture, Michigan State University, East Lansing, \\ MI 48824
}

Additional index words. solar radiation, stevioside, rebaudioside A, Stevia rebaudiana, diterpene glycosides

\begin{abstract}
The biosynthesis of steviol glycosides is affected by both genetic and environmental factors. To evaluate the influence of total daily solar radiation or daily light integral (DLI) under long-day conditions on steviol glycoside concentration, we grew Stevia rebaudiana under ambient irradiance or varying levels of shading at different times of the year in both greenhouse and field environments, resulting in DLIs ranging from 3.55 to $20.31 \mathrm{~mol} \cdot \mathrm{m}^{-2} \cdot \mathrm{d}^{-1}$ in the greenhouse and 10.32 to $39.7 \mathrm{~mol} \cdot \mathrm{m}^{-2} \cdot \mathrm{d}^{-1}$ in the field. Total steviol glycoside concentration of selected leaves from greenhouse-grown plants increased as DLI increased up to ca. $10 \mathrm{~mol} \cdot \mathrm{m}^{-2} \cdot \mathrm{d}^{-1}$, remaining constant with further increases in DLI, and was similar across the range of DLIs evaluated in the field. DLI influenced both the concentration and the relative proportions of specific steviol glycosides. Rebaudioside A concentration increased as DLI increased from 3.55 to 8.53 $\mathrm{mol} \cdot \mathrm{m}^{-2} \cdot \mathrm{d}^{-1}$, remaining similar with further increases in DLI. Rebaudioside D and stevioside concentration of selected leaves from field-grown plants decreased by $22 \%$ and $13 \%$, respectively, as DLI increased from 10.32 to $39.7 \mathrm{~mol} \cdot \mathrm{m}^{-2} \cdot \mathrm{d}^{-1}$, while rebaudioside $A$ and $M$ concentrations remained similar across this DLI range. Collectively, these results indicate that the greatest influence of DLI on steviol glycoside concentration occurs under relatively low DLIs $\left(<\mathbf{1 0} \mathrm{mol} \cdot \mathrm{m}^{-2} \cdot \mathrm{d}^{-1}\right)$. However, higher DLIs can significantly affect the synthesis of minor glycosides of increasing commercial importance including rebaudioside $D$.
\end{abstract}

The production of steviol glycosides in plant species is rare, a characteristic that Stevia rebaudiana shares with only three other known species, Stevia phlebophylla (Kinghorn et al., 1984), Rubus suavissimuss (Ohtani et al., 1992) and Angelica keiskei (Zhou et al., 2012). Steviol glycosides are tetracyclic diterpenes, which share precursors with gibberellins (Brandle and Telmer, 2007). Discovery of new diterpene glycosides has been swift in recent years, and at least 34 steviol glycosides have been identified in S. rebaudiana (Ceunen and Geuns, 2013a).

The diversity of steviol glycosides results from differential glycosylation of the aglycone steviol by several cytosolic Uridine diphosphate (UDP) glycosyltransferases

Received for publication 4 Dec. 2014. Accepted for publication 17 Mar. 2015

This project was supported by PureCircle SDN BHD, the USDA National Institute of Food and Agriculture and AgBioResearch at Michigan State University.

J.M.E. and R.M.W. designed the experiments and wrote the manuscript. J.M.E. conducted the experiments and analyzed data. J.M.E., V.A.V., and R.M.B. conducted the steviol glycoside quantification.

${ }^{1}$ Corresponding author. E-mail: warnerry@msu. edu.
(Brandle and Telmer, 2007). These UDPglycosyltransferases (UGTs) transfer activated sugars, usually UDP-glucose, to acceptor molecules that produce the mixture of glycosides found in the vacuoles of leaf cells of $S$. rebaudiana (Richman et al., 2005). The enzymes catalyzing steps in the steviol glycoside biosynthetic pathway are beginning to be elucidated, including the glycosylation of steviol by UGT85C2, the first step in steviol glycoside formation, to form steviolmonoside (Mohamed et al., 2011). Stevioside, a triglycoside, and rebaudioside A, a tetra-glycoside, are typically produced in the highest concentrations while glycosides, including rebaudioside $\mathrm{B}$ (triglycoside), rebaudioside $\mathrm{C}$ (tetra-glycoside), rebaudioside $\mathrm{D}$ (penta-glycoside), and rebaudioside $\mathrm{M}$ (hexa-glycoside; also known as rebaudioside $\mathrm{X}$ ) are typically produced in much lower concentrations (Kennelly, 2002). UGTs are not specific to $S$. rebaudiana and play a large role in the diversity of secondary metabolites produced by plant species (Richman et al., 2005). At least 12 UGTs have been identified in $S$. rebaudiana, but only three have been directly linked to steviol glycoside synthesis (Ceunen and Geuns, 2013a; Richman et al., 2005).

Several studies have explored the effects of photoperiod (Ceunen and Geuns, 2013b: Metivier and Viana, 1979; Valio and Rocha, 1977; Zaidan et al., 1980) and the effects of light quality, specifically, red light (Ceunen and Geuns, 2013b; Ceunen et al., 2012) on steviol glycoside accumulation in $S$. rebaudiana. However, the effects total daily radiation or the DLI have yet to be elucidated. Previous studies have quantified biomass yield potential under a range of DLIs under long photoperiods, however, no glycoside data were reported (Ermakov and Kochetov, 1996). A more recent study found that a reduction in light did not significantly affect steviol glycoside concentrations except at the crop development period described as the flower initiation stage, where rebaudioside A levels were significantly higher with $25 \%$ light reduction (Kumar et al., 2013). However, only stevioside and rebaudioside A levels were reported. The effect of DLI on synthesis of rebaudiosides $\mathrm{B}, \mathrm{C}, \mathrm{D}$, and $\mathrm{M}$ has not previously been reported. The objective of this study was to evaluate the influence of DLI during long days on the concentrations and relative proportions of several steviol glycosides. Experiments were conducted in both greenhouse and field environments to create a wide range of DLIs.

\section{Materials and Methods}

\section{Experiment 1}

Plant material and propagation. On 14 Feb. 2012 (run 1) and again on 24 July 2012 (run 2), two Stevia rebaudiana selections from an open-pollinated population, designated 10-43-41 and 11-464, were vegetatively propagated into plug trays [128-cell size (12 mL volume)] in a soilless medium consisting of $50 \%$ fine perlite (Perlite Vermiculite Packaging Industries Inc., North Bloomfield, $\mathrm{OH}$ ) and 50\% potting mix composed of peat, perlite, lime, and starter fertilizer (Suremix Perlite; Michigan Grower Products Inc., Galesburg, MI). The cuttings were rooted in a glass-covered greenhouse under a 16-h photoperiod [ambient daylight plus day-extension lighting provided by highpressure sodium (HPS) lamps from 0600 to $2200 \mathrm{HR}]$ at an air temperature of $24{ }^{\circ} \mathrm{C}$ and bench temperature of $26^{\circ} \mathrm{C}$. Bench temperature was regulated by running hot water through tubes inlayed in a Styrofoam sheet on the benchtop. The watering regime consisted of intermittent overhead mist supplemented with a water-soluble fertilizer providing (mg. $\left.\mathrm{L}^{-1}\right) 50 \mathrm{~N}, 8 \mathrm{P}, 42 \mathrm{~K}, 22 \mathrm{Ca}, 12 \mathrm{Mg}, 1.0 \mathrm{Fe}$ and $\mathrm{Cu}, 0.5 \mathrm{Mn}$ and $\mathrm{Zn}, 0.3 \mathrm{~B}$, and $0.1 \mathrm{Mo}$ (MSU Prop Special; GreenCare Fertilizers Inc., Kankakee, IL). When plant roots reached all corners of the plug cell, rooted cuttings were transplanted into $10-\mathrm{cm}$ round plastic containers (480 mL volume) filled with $100 \%$ Suremix Perlite potting mix and moved to the greenhouse environment described below.

Greenhouse environment and plant culture. Plants were grown under a photoperiod of $16 \mathrm{~h}$ (0600 to $2200 \mathrm{HR}$ ) achieved by supplementing the natural photoperiod $\left(42^{\circ} \mathrm{N}\right.$ lat.) with day-extension lighting provided by 400 W HPS lamps (LU400; GE, Mississaugua, Canada) supplying a supplemental photosynthetic photon flux of $90 \mu \mathrm{mol} \cdot \mathrm{m}^{-2} \cdot \mathrm{s}^{-1}$ at plant 
Table 1. Average daily light integrals (DLI) with standard deviations, DLI minimum and maximum for each treatment and $24-\mathrm{h}$ mean temperature $\left({ }^{\circ} \mathrm{C}\right)$ with standard deviation for each DLI treatment created with shadecloth over two periods in Michigan State University greenhouses during 2012.

\begin{tabular}{lccc}
\hline Date range & $\begin{array}{c}\text { DLI }\left(\mathrm{mol} \cdot \mathrm{m}^{-2} \cdot \mathrm{d}^{-1}\right) \\
\text { mean } \pm \mathrm{sD}\end{array}$ & $\begin{array}{c}\mathrm{DLI}\left(\mathrm{mol} \cdot \mathrm{m}^{-2} \cdot \mathrm{d}^{-1}\right) \\
\mathrm{min}-\mathrm{max}\end{array}$ & $\begin{array}{c}\text { Temperature }\left({ }^{\circ} \mathrm{C}\right) \\
\text { 24-h } \mathrm{mean} \pm \mathrm{SD}\end{array}$ \\
\hline 5 Oct.-7 Dec. & $3.55 \pm 1.15$ & $1.61-6.26$ & $19.88 \pm 1.30$ \\
& $5.67 \pm 1.39$ & $3.12-9.03$ & $20.57 \pm 1.58$ \\
& $10.50 \pm 2.34$ & $6.23-17.96$ & $20.38 \pm 1.38$ \\
3 May-5 July & & & \\
& $11.87 \pm 2.18$ & $3.03-12.22$ & $23.21 \pm 3.23$ \\
& $20.31 \pm 4.51$ & $5.19-15.72$ & $24.45 \pm 4.01$ \\
& & $10.55-29.23$ & $24.06 \pm 3.66$ \\
\hline
\end{tabular}

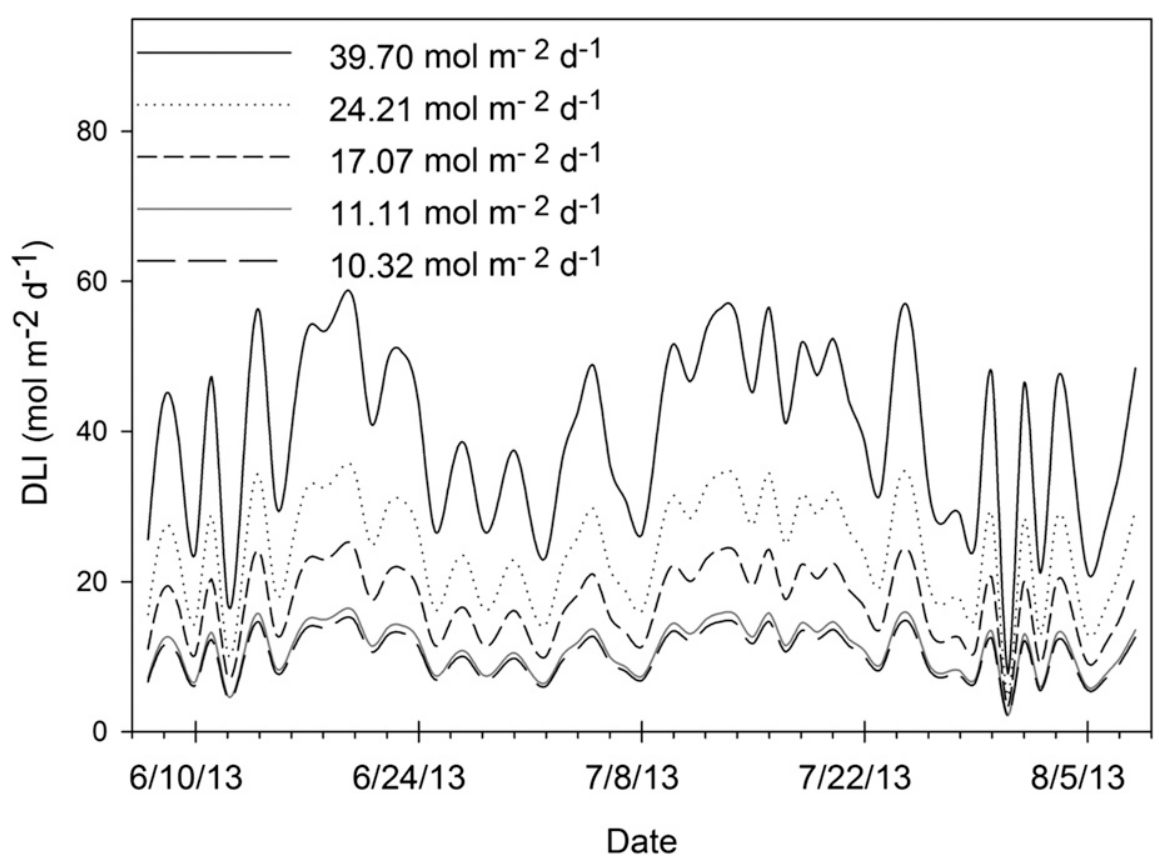

Fig. 1. Daily light integrals (DLIs; labeled by average treatment DLI) for field-grown stevia in expt. 2 from 7 June to 8 Aug. 2013.

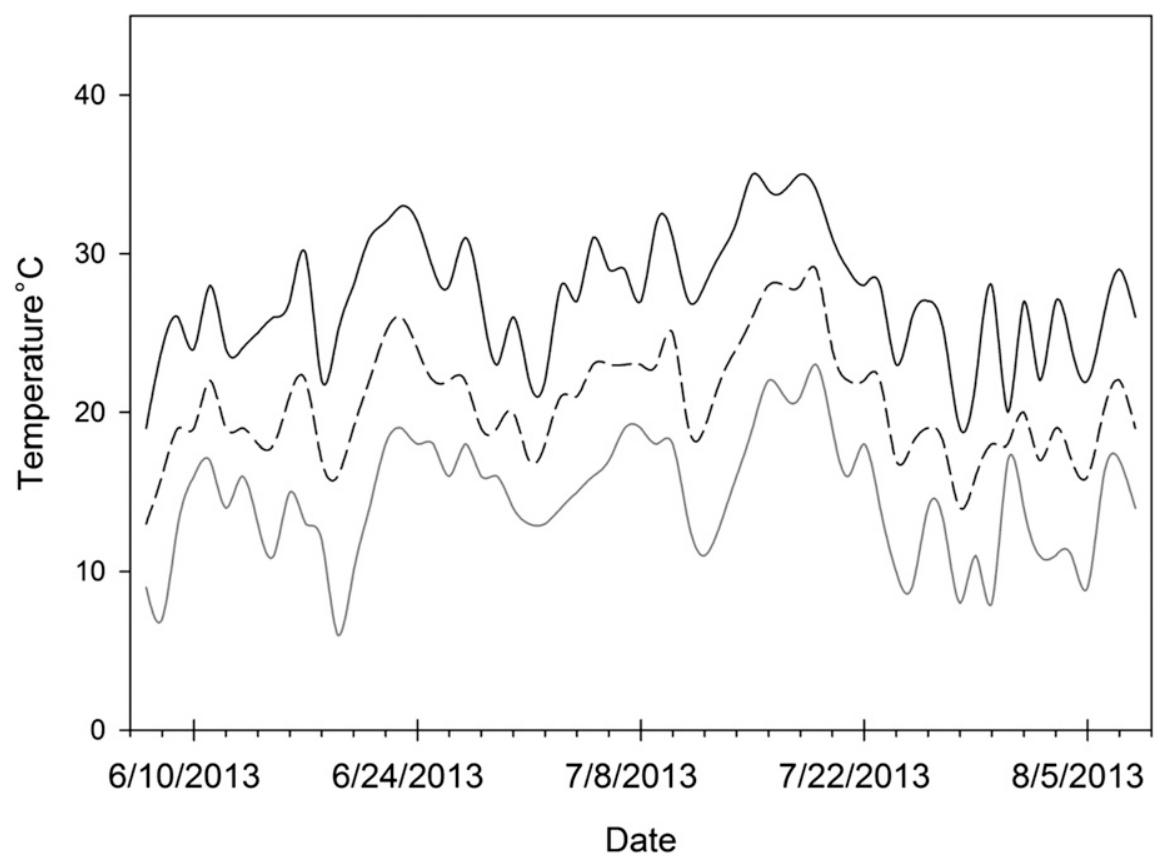

Fig. 2. Daily high (solid black line), low (solid grey line) and 24-h average (dashed line) ambient temperatures for field-grown stevia (expt. 2) from 7 June to 8 Aug. 2013. height as measured by a custom-made line quantum sensor with 10 photodiodes (Apogee Instruments Inc., Logan, UT). The HPS lamps were operated by an environmental control computer (Priva Integro 724; Priva, Vineland Station, Ontario, Canada). When irradiance was less than $580 \mu \mathrm{mol} \cdot \mathrm{m}^{-2} \cdot \mathrm{s}^{-1}$ for at least 10 min supplemental lighting was activated. Lighting would shut off only when irradiance was greater than $580 \mu \mathrm{mol} \cdot \mathrm{m}^{-2} \cdot \mathrm{s}^{-1}$ for a minimum of $20 \mathrm{~min}$. Average temperatures and standard deviations are reported in Table 1. Plants were irrigated as needed with reverse osmosis water supplemented with a water-soluble fertilizer supplying $\left(\mathrm{mg} \cdot \mathrm{L}^{-1}\right)$ $125 \mathrm{~N}, 12 \mathrm{P}, 100 \mathrm{~K}, 65 \mathrm{Ca}, 12 \mathrm{Mg}, 1.0 \mathrm{Fe}$ and $\mathrm{Cu}, 0.5 \mathrm{Mn}$ and $\mathrm{Zn}, 0.3 \mathrm{~B}$, and 0.1 Mo (MSU RO Water Special; GreenCare Fertilizers Inc.). On 17 Apr. 2012 (run 1) and 1 Oct. 2012 (run 2) plants were pinched back one node and sprayed with $200 \mathrm{mg} \cdot \mathrm{L}^{-1}$ ethephon (Florel; Southern Agricultural Insecticides Inc., Hendersonville, NC) diluted with reverse osmosis water to abort any flower buds that may have been present. At the onset of the experiment, the number of lateral branches exceeding $3 \mathrm{~cm}$ in length and the number of nodes per branch were recorded and 36 representative plants per genotype were selected for the experiment. Each DLI environment described below was replicated three times, and each replicate consisted of four plants per genotype. Plants were placed into their respective treatments on 3 May 2012 (run 1) and 5 Oct. 2012 (run 2), and spaced $23 \mathrm{~cm}$ from midpot to midpot. After 4 weeks in treatment, all plants were repotted into $15-\mathrm{cm}$ square plastic containers $(2506 \mathrm{~mL})$ filled with the same medium and spaced $36 \mathrm{~cm}$ from midpot to midpot. Plants were grown in treatment for 9 weeks following the ethephon application.

DLI treatments. Six different DLIs were created using two different woven shadecloths (OLS 50, OLS 30; Ludvig Svensson Inc., Charlotte, NC) or no shadecloth, over two time periods (May-July and OctoberDec. 2012, runs 1 and 2, respectively), resulting in average DLIs ranging from 3.55 to $20.31 \mathrm{~mol} \cdot \mathrm{m}^{-2} \cdot \mathrm{d}^{-1}$ (Table 1 ).

Tissue sampling and steviol glycoside analysis. Following 9 weeks in treatments, leaf tissue samples were collected for quantification of steviol glycosides. Ten fully expanded leaves selected from about $66 \%$ of the height of the plant (from the base) were collected (representing young, but fully expanded leaves) and dried at $65^{\circ} \mathrm{C}$ for at least $72 \mathrm{~h}$, then transferred to $15-\mathrm{mL}$ conical tubes and held at $-20{ }^{\circ} \mathrm{C}$. Ten samples per genotype from each treatment and replicate were selected for analysis. Samples were allowed to warm to room temperature before seven stainless steel ball bearings $(3.97 \mathrm{~mm}$ diameter, 440C-G16, VXB Ball Bearings; NationSkander California Corp., Anaheim, CA) were added to each tube. Samples were ground via shaking with an adapted paint shaker for $15 \mathrm{~min}$ until the sample was a fine powder. Ten to twelve milligram samples were transferred to $1.5-\mathrm{mL}$ centrifuge tubes and the mass was recorded for each sample. 
One milliliter of extraction buffer (final concentration $6.78 \mathrm{M}$ ethanol, and $0.1 \mathrm{~mm}$ digitoxin) was added to each sample. Samples were shaken using a vortex mixer with microtube foam insert (Scientific Industries Inc., Bohemia, NY) for $10 \mathrm{~min}$ at room temperature. Samples were then centrifuged at $21,000 g_{\mathrm{n}}$ for $10 \mathrm{~min}$ at $4{ }^{\circ} \mathrm{C}$. The supernatant was transferred to a new $1.5-\mathrm{mL}$ centrifuge tube. Extract supernatant was prepared for analysis by using a Millipore deep well filter plate and deep well 96-well receiving plate (Millipore Corporation, Billerica, MA) as previously described by Shafii et al. (2012). quantified by ultra-high performance liquid chromatography-tandem mass spectrometry as previously described (Shafii et al., 2012) with the addition of rebaudioside D quantification with the following parameters: multiple reaction monitoring (MRM) transition $\mathrm{m} / \mathrm{z}$ $1127>803$, retention time $2.6 \mathrm{~min}$, declustering potential $-35 \mathrm{~V}$, entrance potential $-10 \mathrm{~V}$,

Morphological data collection. At the time of tissue collection for glycoside analysis, the number of nodes on the tallest branch (opposite and alternate nodes were each counted as one), canopy height (cm, from soil line to tallest point), and average leaf area (one leaf measured twice collected from the seventh node down from the apex of the tallest branch) were determined. Leaf area was calculated by averaging two measurements of the same leaf using a leaf area meter (LI-3000; LI-COR, Lincoln, NE).

Statistical analysis. Six DLI environments were generated over the two runs. Normality of all data was evaluated by applying the

Table 2. Average daily light integrals (DLI) with standard deviations, DLI minimum and maximum (24 $\mathrm{h}$ mean) for each treatment created with shadecloth in a field experiment (expt. 2) from 7 June to 8 Aug. 2013.

\begin{tabular}{lcc}
\hline $\begin{array}{l}\text { Treatment } \\
(\% \text { of }\end{array}$ & DLI $\left(\mathrm{mol} \cdot \mathrm{m}^{-2} \cdot \mathrm{d}^{-1}\right)$ & \\
full light $)$ & mean $\pm \mathrm{SD}$ & DLI min-max \\
\hline 26 & $10.32 \pm 3.03$ & $2.01-14.78$ \\
28 & $11.11 \pm 3.26$ & $2.16-15.91$ \\
43 & $17.07 \pm 5.01$ & $3.32-24.44$ \\
61 & $24.21 \pm 7.11$ & $4.71-34.67$ \\
100 & $39.70 \pm 11.66$ & $7.72-56.83$ \\
\hline
\end{tabular}
Stevioside and rebaudiosides A, B, and C were and collision potential $-45 \mathrm{~V}$.
Shapiro-Wilk statistic to the residuals of the data in PROC UNIVARIATE procedure in SAS version 9.3 (SAS Institute, Cary, NC). Homogeneity of variances was confirmed by examining residual plots. Concentrations of stevioside and rebaudiosides A, C, and D $(\log$ transformation) and proportion of rebaudioside B (square root transformation) were transformed to meet analysis of variance (ANOVA) assumptions for normality. ANOVA and means separation (Tukey's HSD $(0.05)$ ) were conducted using PROC GLM.

\section{Experiment 2}

Plant material and propagation. On 27 Mar. 2013, genotype 10-43-41 was propagated by cuttings into plug trays [72-cell size square (59 $\mathrm{mL}$ volume)] in the same soilless medium and propagation environment as described in experiment 1. On 24 Apr. 2013, when plant roots reached all corners of the plug cell and vegetative growth was observed, rooted cuttings were transplanted into larger plug trays [50-cell size, round (76 $\mathrm{mL}$ volume)] with media composed of $100 \%$ Suremix Perlite potting mix.

Field environment and plant culture. On 7 June 2013, four plants were transplanted into each of five plots in each of three white plastic-covered north-south-oriented raised rows ( $15 \mathrm{~cm}$ high by $66 \mathrm{~cm}$ wide), for a total of 15 plots, in a capac loam soil field at the Michigan State University Horticulture Teaching and Research Center (Holt, MI). Soil $\mathrm{pH}$ measured was at 6.7 and the average electrical conductivity (EC) was $0.51 \mathrm{mS}$. Transplants were positioned in two staggered north-south rows per plastic-covered row, set $15 \mathrm{~cm}$ inside from each plastic-covered row edge. Within-row spacing was $46 \mathrm{~cm}$ and between-row spacing was $36 \mathrm{~cm}$. Irrigation was supplied via natural rainfall as well as by drip tape underneath the plastic in each row. Supplemental irrigation was used only on four dates: 15, 17, 25, and 26 July 2013, when the soil did not contain sufficient water to clump together when squeezed. Preplant fertilizer was applied supplying $(\mathrm{kg} / \mathrm{ha}) 79.9 \mathrm{~N}$, $34.9 \mathrm{P}$, and $66.3 \mathrm{~K}$. The light environment was created by the natural photoperiod and DLI (42 ${ }^{\circ} \mathrm{N}$ latitude). Minimum, maximum, and average daily temperature and DLI was recorded by a miniature weather station situated near the experimental treatments (Watch Dog WeatherTracker Model 305; Spectrum Technologies, Aurora, IL). The average temperatures with standard deviation for each minimum, maximum, and average daily temperatures were $14.6 \pm 3.8,27.30 \pm 3.9$, and $20.56 \pm 3.5{ }^{\circ} \mathrm{C}$, respectively. Temperatures ranged from 6 to $35^{\circ} \mathrm{C}$ over the course of the experiment. Daily light integrals and temperatures for the experimental period were recorded (Figs. 1 and 2). The experiment ran for 8 weeks.

DLI treatments. To create different DLI environments within the field, metal conduit frames were constructed and covered with one of three different woven shadecloths (Ludvig Svensson Inc.) independently (OLS 60 , OLS 50, OLS 30), a combination of two shadecloths to achieve a heavy shade treatment (OLS 40 plus OLS 30), or no shadecloth, resulting in DLIs averaging from 10.32 to $39.70 \mathrm{~mol} \cdot \mathrm{m}^{-2} \cdot \mathrm{d}^{-1}$ (Table 2 ).

Tissue sampling and steviol glycoside analysis. Following 8 weeks in treatments, tissue samples were collected from each plant individually for quantification of steviol glycosides as described for experiment 1. Samples were ground, extracted, and analyzed for steviol glycoside concentrations as described for experiment 1, with the exception that rebaudioside $\mathrm{M}$ was quantified with the following parameters: multiple reaction monitoring transition $\mathrm{m} / \mathrm{z} 1289>803$, retention time $2.8 \mathrm{~min}$, declustering potential $-45 \mathrm{~V}$, entrance potential $-4 \mathrm{~V}$ and collision potential $-60 \mathrm{~V}$, while rebaudioside B was not quantified.

Statistical analysis. The experiment employed a randomized complete block design, with each of three plastic-covered rows representing a block. Spacing between treatments within a block was $200 \mathrm{~cm}$. DLI treatments were randomized within a block. Normality of the data was evaluated by applying the Shapiro-Wilk statistic to the residuals of the data in PROC UNIVARIATE procedure in SAS version 9.3. Homogeneity of variances was confirmed by examining residual plots. After removing one outlier from the $11.11 \mathrm{~mol} \cdot \mathrm{m}^{-2} \cdot \mathrm{d}^{-1}$ treatment group, data met ANOVA assumptions. ANOVA and means separation (Tukey's $\operatorname{HSD}_{(0.05)}$ ) were conducted using PROC GLM.

\section{Results}

Table 3. Influence of daily light integral (DLI) on plant canopy height (cm), node number (count), and leaf area $\left(\mathrm{cm}^{2}\right)$ from selected leaves of two greenhouse-grown stevia genotypes exposed to six different DLIs

\begin{tabular}{lccccc}
\hline Genotype & Run & $\begin{array}{c}\text { DLI }\left(\mathrm{mol} \cdot \mathrm{m}^{-2} \cdot \mathrm{d}^{-1}\right) \\
(\mathrm{mean} \pm \mathrm{SD})\end{array}$ & $\begin{array}{c}\text { Canopy ht } \\
(\mathrm{cm})\end{array}$ & Node number & $\begin{array}{c}\text { Individual leaf area } \\
\left(\mathrm{cm}^{2}\right)\end{array}$ \\
\hline $10-43-41$ & 1 & $8.53 \pm 2.18$ & $59.20 \mathrm{ab}$ & $19.5 \mathrm{a}$ & $14.21 \mathrm{bc}$ \\
& & $11.87 \pm 2.65$ & $58.00 \mathrm{a}$ & $20.0 \mathrm{a}$ & $12.54 \mathrm{ab}$ \\
& $20.31 \pm 4.51$ & $52.80 \mathrm{a}$ & $19.8 \mathrm{a}$ & $9.85 \mathrm{a}$ \\
& 2 & $3.55 \pm 1.15$ & $74.14 \mathrm{c}$ & $20.8 \mathrm{a}$ & $17.01 \mathrm{c}$ \\
$11-464$ & $5.67 \pm 1.39$ & $70.84 \mathrm{c}$ & $20.1 \mathrm{a}$ & $12.98 \mathrm{ab}$ \\
& & $10.50 \pm 2.34$ & $66.40 \mathrm{bc}$ & $20.2 \mathrm{a}$ & $10.15 \mathrm{a}$ \\
& \multirow{2}{*}{1} & $8.53 \pm 2.18$ & $46.10 \mathrm{a}$ & $23.2 \mathrm{a}$ & $7.17 \mathrm{c}$ \\
& & $11.87 \pm 2.65$ & $45.90 \mathrm{a}$ & $26.1 \mathrm{ab}$ & $6.85 \mathrm{c}$ \\
& $20.31 \pm 4.51$ & $44.70 \mathrm{a}$ & $23.0 \mathrm{a}$ & $6.45 \mathrm{bc}$ \\
& 2 & $3.55 \pm 1.15$ & $55.28 \mathrm{~b}$ & $30.3 \mathrm{bc}$ & $6.17 \mathrm{bc}$ \\
& & $5.67 \pm 1.39$ & $53.19 \mathrm{~b}$ & $31.3 \mathrm{c}$ & $5.48 \mathrm{~b}$ \\
& & $10.50 \pm 2.34$ & $51.72 \mathrm{~b}$ & $34.7 \mathrm{c}$ & $4.41 \mathrm{a}$ \\
\hline
\end{tabular}

Column means $(\mathrm{n}=10)$ were analyzed by genotype, different letters indicate significant differences across DLI treatment within a genotype as determined by Tukey's $\operatorname{HSD}_{(0.05)}$.

\section{Experiment 1}

Morphological traits. Morphological traits were differentially affected by DLI, run, and genotype. Node number for 10-4341 did not differ between DLIs or runs, whereas node number for 11-464 varied between runs but was not influenced by DLI (Table 3). Plant height was influenced by genotype and run. Genotype 10-43-41 was always taller than 11-464 within a treatment and run, and plant heights for run 2 were taller than plants in run 1 at comparable DLIs for both genotypes. Leaf area was affected by DLI and genotype, with leaf area generally decreasing as DLI increased (Table 3 ).

Steviol glycoside concentrations. Individual glycoside concentrations were differentially 


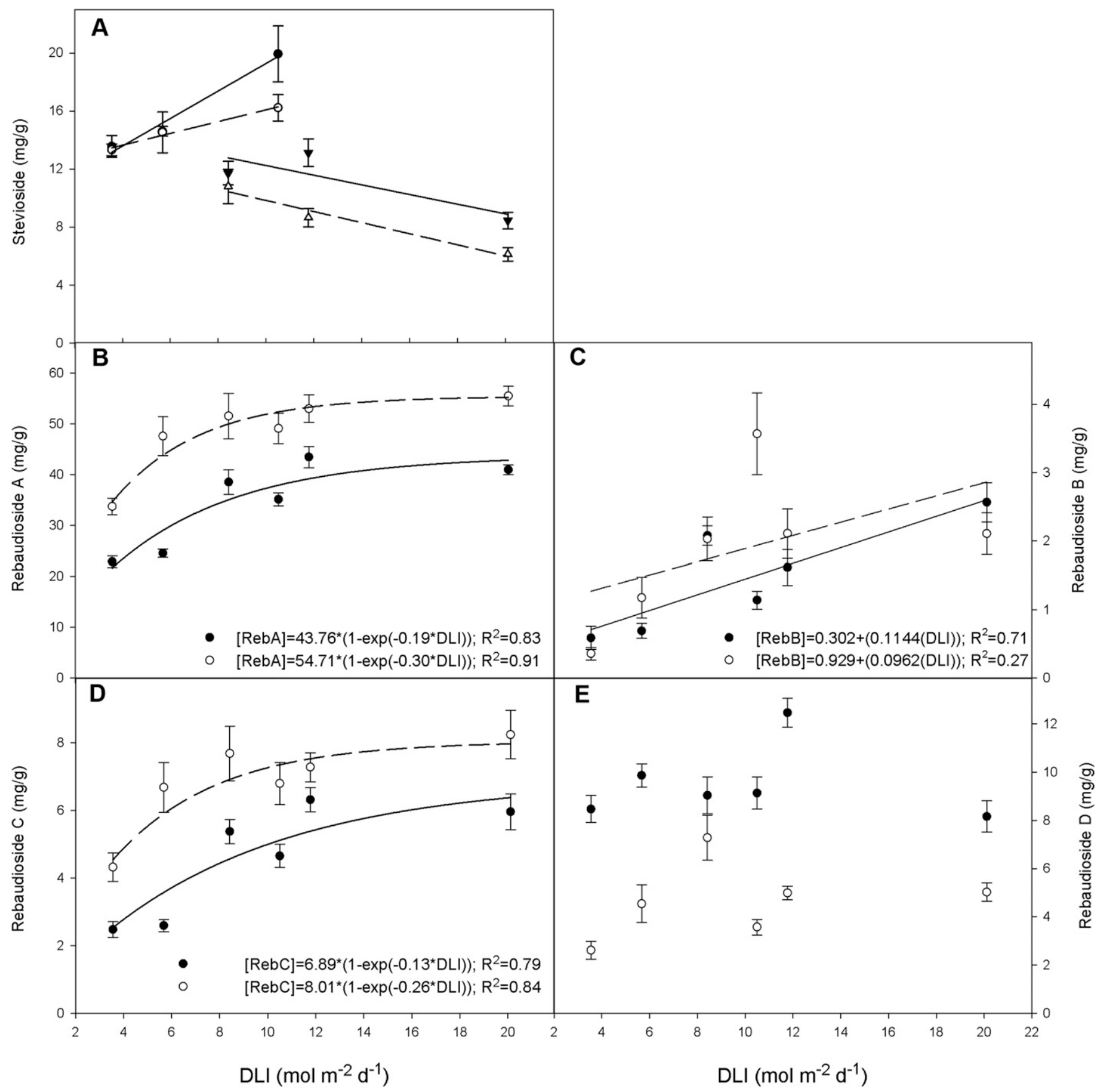

Fig. 3. Influence of daily light integral (DLI) under a 16-h photoperiod on concentration (mg/g) of (A) stevioside, (B) rebaudioside A, (C) rebaudioside B, (D) rebaudioside C, and (E) rebaudioside D for two greenhouse-grown (expt. 1) stevia genotypes, 10-43-41 (filled symbols) and 11-464 (open symbols). For stevioside, triangles represent run 1 and circles represent run 2 .

affected by DLI and genotype (Fig. 3). Stevioside concentration was affected by a DLI $\times$ run interaction, so runs were analyzed independently. Stevioside increased as DLI increased from 3.55 to $10.5 \mathrm{~mol} \cdot \mathrm{m}^{-2} \cdot \mathrm{d}^{-1}$ in run 2 , but decreased as DLI increased from 8.53 to $20.3 \mathrm{~mol} \cdot \mathrm{m}^{-2} \cdot \mathrm{d}^{-1}$ in run 1 (Fig. 3A). Rebaudioside $\mathrm{A}$ and rebaudioside $\mathrm{C}$ concentrations increased for both genotypes as DLI increased from 3.55 to $8.53 \mathrm{~mol} \cdot \mathrm{m}^{-2} \cdot \mathrm{d}^{-1}$ (Fig. 3B and D), while further increases in DLI did not increase concentration of either glycoside. Genotype 11-464 produced a higher rebaudioside $\mathrm{A}$ and C concentration than 10-43-41, regardless of DLI. Rebaudioside B concentration was low
( $<4 \mathrm{mg} / \mathrm{g}$ ) for both genotypes, regardless of DLI, but increased linearly for both genotypes as DLI increased (Fig. 3C). The concentration of rebaudioside D was not significantly influenced by DLI (Fig. 3E). Genotype 10-43-41 had a higher rebaudioside D concentration than genotype 11464, regardless of DLI. Total steviol glycoside concentration (the sum of the five glycosides assayed) increased as DLI increased up to ca. $8.53 \mathrm{~mol} \cdot \mathrm{m}^{-2} \cdot \mathrm{d}^{-1}$ for both genotypes (Fig. 4), while further increases in DLI did not increase total glycoside concentrations. Genotype 11-464 generally produced higher total steviol glycoside concentrations than 10-43-41 across the range of DLIs examined.
Steviol glycoside proportions. The relative proportions of individual glycosides (percentage of individual glycoside calculated from total glycosides) were all affected by DLI (Fig. 5). The proportion of stevioside was highest at the lowest DLI of $3.55 \mathrm{~mol} \cdot \mathrm{m}^{-2} \cdot \mathrm{d}^{-1}$, and lowest at the highest DLI of $20.31 \mathrm{~mol} \cdot \mathrm{m}^{-2} \cdot \mathrm{d}^{-1}$, although the proportions varied by genotype and were also affected by run. Rebaudioside $A$ and rebaudioside $\mathrm{C}$ proportion generally increased as DLI increased and were highest at the highest DLI $\left(20.31 \mathrm{~mol} \cdot \mathrm{m}^{-2} \cdot \mathrm{d}^{-1} ;\right.$ Fig. 5). The proportion of rebaudioside $\mathrm{D}$ was affected by the interaction of all three main effects, DLI $x$ genotype $\times$ run. The maximum percentage 


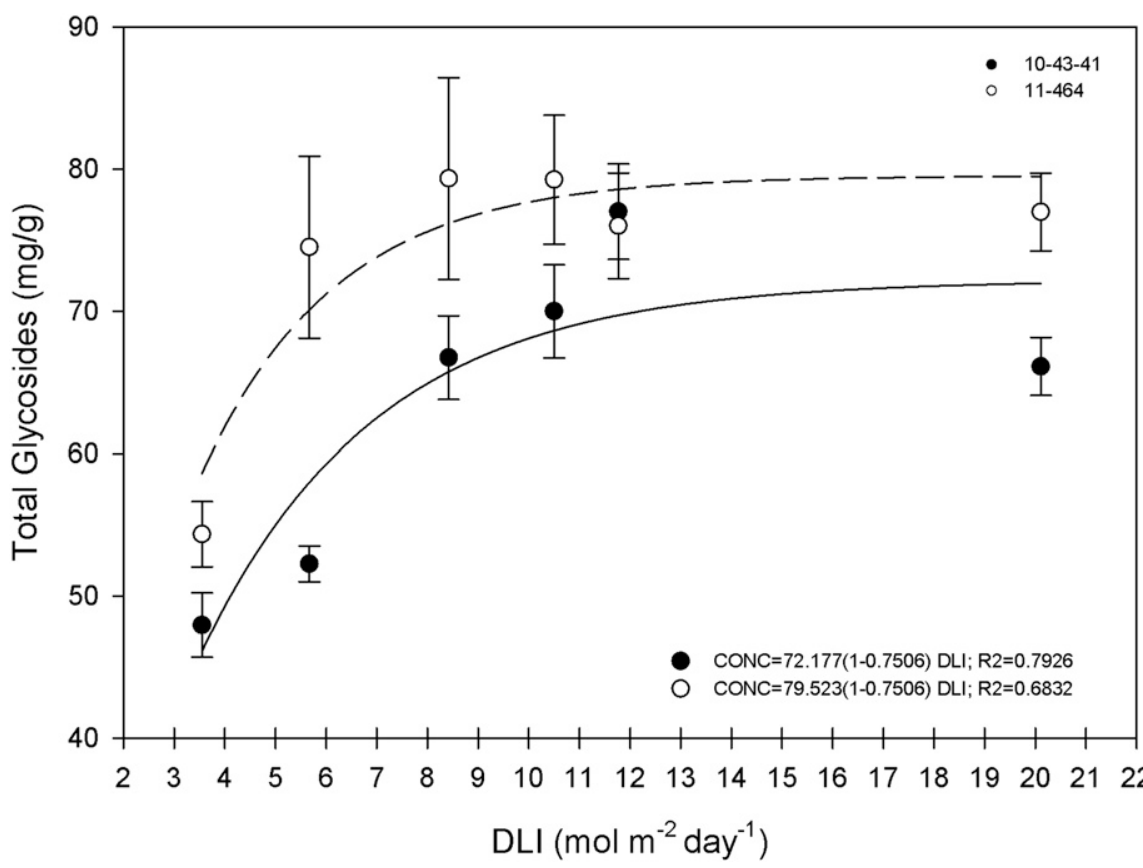

Fig. 4. Influence of greenhouse daily light integral (DLI) under a 16-h photoperiod on total steviol glycoside concentration (mg/g) for two greenhouse-grown (expt. 1) stevia genotypes.

occurred at a DLI of $5.67 \mathrm{~mol} \cdot \mathrm{m}^{-2} \cdot \mathrm{d}^{-1}$, which only differed from the "full light" $\left(10.50\right.$ and $\left.20.31 \mathrm{~mol} \cdot \mathrm{m}^{-2} \cdot \mathrm{d}^{-1}\right)$ treatments from each run. Genotype 10-43-41 had higher proportions of rebaudioside D compared with 11464 (Fig. 5).

\section{Experiment 2}

Steviol glycoside concentrations and proportions. Concentrations of stevioside and rebaudioside D decreased as DLI increased from $10.32 \mathrm{~mol} \cdot \mathrm{m}^{-2} \cdot \mathrm{d}^{-1}$ to $39.70 \mathrm{~mol} \cdot \mathrm{m}^{-2} \cdot \mathrm{d}^{-1}$ (Table 4). Rebaudioside A, C, and M concentrations, as well as total steviol glycosides, were not significantly influenced by DLI. The relative proportion of stevioside and rebaudioside D decreased as DLI increased from 10.32 to $39.70 \mathrm{~mol} \cdot \mathrm{m}^{-2} \cdot \mathrm{d}^{-1}$ (Table 4), while the relative proportion of rebaudioside $\mathrm{A}$ and rebaudioside $\mathrm{C}$ increased as DLI increased. The proportion of rebaudioside $\mathrm{M}$ was not influenced by DLI.

\section{Discussion}

Environmental parameters, specifically the irradiance parameters photoperiod and light quality, can affect steviol glycoside synthesis (Ceunen and Geuns, 2013b; Ceunen et al., 2012). Our results demonstrate that for stevia plants grown under long days, DLI affects glycoside concentration as well as the relative proportions of specific glycosides, particularly as DLI increases up to ca. 10 $\mathrm{mol} \cdot \mathrm{m}^{-2} \cdot \mathrm{d}^{-1}$. The two genotypes evaluated here responded similarly to DLI, though glycoside concentrations varied by genotype.

Varying irradiance levels could affect steviol glycoside biosynthesis by influencing photosynthetic production and overall substrate availability, and/or by differentially influencing efficiency of specific steps in the steviol glycoside biosynthetic pathway. Previously, total steviol glycoside concentration in plants grown in vitro increased over 4-fold as media sucrose concentration increased from $3 \%$ to $5 \%$ (Guleria et al., 2011), which the authors attributed to an enhancement of the transcriptional triggers for genes involved in steviol glycoside biosynthesis. In this study, total steviol glycoside concentration increased as DLI increased to ca. $8-10 \mathrm{~mol} \cdot \mathrm{m}^{-2} \cdot \mathrm{d}^{-1}$, above which total steviol glycoside concentration was similar, suggesting that steviol glycoside synthesis may be constrained by primary productivity under low DLIs. In support of this, (Guleria et al., 2011) determined that expression of several genes important in early steps in the steviol glycoside biosynthetic pathway, including copalyl diphosphate synthase, kaurene oxidase, and kaurene synthase, which function upstream of steviol synthesis, and the UGT gene $U G T 85 C 2$, which encodes the enzyme that catalyzes glycosylation of steviol to form steviolmonoside (Richman et al., 2005), increased as media sucrose concentration increased from $1 \%$ to $5 \%$. However, abundance and activity of these enzymes in response to DLI have yet to be determined.

The availability of sucrose may also indirectly influence the production and/or accumulation of particular glycosides by altering expression of UGT76G1. UGT76G1, which is known to be involved in several steps in the pathway, including the glycosylations of stevioside to form rebaudioside $\mathrm{A}$, dulcoside $\mathrm{A}$ to form rebaudioside $\mathrm{C}$ and steviolbioside to form rebaudioside $\mathrm{B}$, exhibited increased expression as sucrose concentration increased from $1 \%$ to $5 \%$ (Guleria et al., 2011). These three compounds, which were quantified in expt. 1 (rebaudiosides A, B, and C) and expt. 2 (rebaudiosides $\mathrm{A}$ and $\mathrm{C}$ only), all increased in both concentration (Fig. 3) and/or relative proportion (Table 4; Fig. 5) as DLI increased. In contrast to rebaudiosides $\mathrm{A}, \mathrm{B}$, and $\mathrm{C}$, concentration of rebaudioside $\mathrm{D}$ did not increase with increasing DLI in expt. 1 (Fig. 3E), and decreased as DLI increased from 10.32 to 39.7 in expt. 2 (Table 4 ). The relative proportion of rebaudioside $\mathrm{D}$ decreased with increasing DLI in both experiments (Fig. 5; Table 4). Since rebaudioside A is the major precursor for rebaudioside $\mathrm{D}$, it does not appear that rebaudioside D synthesis is being limited by precursor availability.

Experiments 1 and 2 were conducted in a greenhouse and field, respectively, to achieve a wide range of DLIs. The DLIs employed in the two experiments overlapped in the range of ca. $10-20 \mathrm{~mol} \cdot \mathrm{m}^{-2} \cdot \mathrm{d}^{-1}$. The concentrations of steviol glycosides within this range were similar between the two experiments with the exception of stevioside. Stevioside concentrations were 2.5- to 3 -fold higher in the field (expt. 2) than in the greenhouse (expt. 1) within this DLI range (Table 4; Fig. 3A). Because these environments could not be identical, other factors aside from DLI may have played a role in the observed variation. Brandle and Rosa (1992) stated that glycoside levels in leaf tissue can be affected by environment, particularly agronomic practices, which Shock (1982) specified as fertilizer inputs and harvest regimes. The effects of daylength have also been examined and found to be important for glycoside accumulation (Metivier and Viana, 1979) as well as the spatiotemporal allocation of those glycosides (Ceunen and Geuns, 2013b). However, the daylength differences between the two experiments were minimal.

One of the largest differences between the growing conditions in expt. 1 vs. expt. 2 was the fluctuation in day and night temperature. Experiment 1 was conducted in a greenhouse under constant temperature conditions. Since expt. 2 was performed outdoors, the plants were subjected to a wider range of temperatures (Table 2; Fig. 2), and a positive difference (DIF) between temperature during the light and dark periods. DIF has been shown to influence secondary metabolite concentration. Specifically, a greater positive DIF increased anthocyanin content in Perilla frutescens var. acuta (Park et al., 2013). Whether day/night temperature fluctuation compared with constant temperature influences steviol glycoside synthesis is not known.

Stevioside concentration was also more variable between runs 1 and 2 of expt. 1 than any other glycoside evaluated. One environmental difference between the two runs of expt. 1 is a contrast in light quality due to differing amounts of time that supplemental lighting was employed. High-pressure sodium lamps deliver a higher ratio of red to far-red light than natural sunlight (Ballare and Scopel, 1994). Red to far-red ratio influences phytochrome photoequilibria and phytochrome signaling (Franklin and Quail, 2010) resulting in differential gene expression. One study examining the effects of red light on steviol glycoside biosynthesis found that plants exposed 


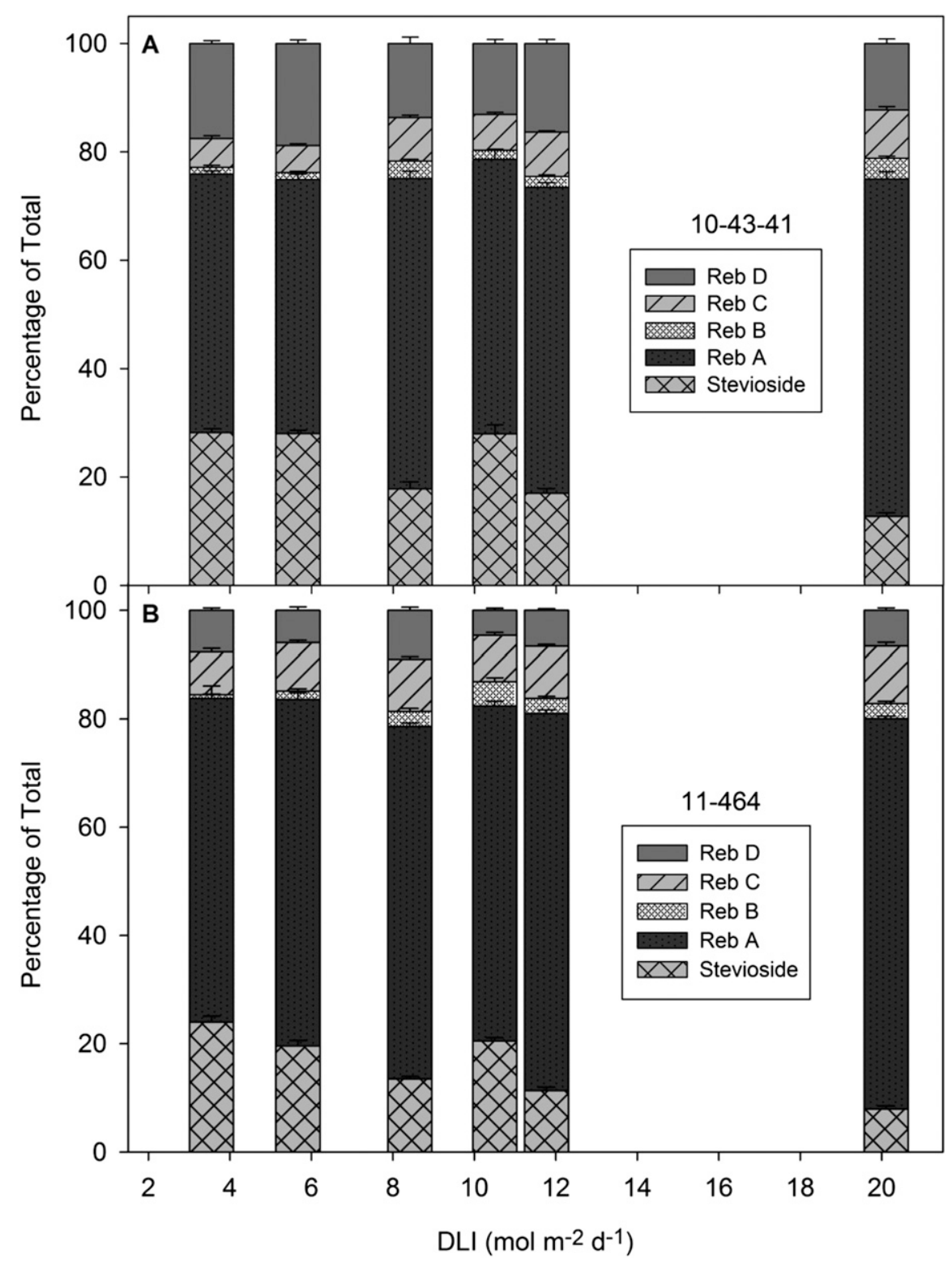

Fig. 5. Proportions of stevioside and rebaudiosides A-D for each of the six average DLIs for greenhousegrown (expt. 1) stevia genotypes (A) 10-43-41 and (B) 11-464 under a 16-h photoperiod.

Table 4. Mean concentrations $(\mathrm{mg} / \mathrm{g} ; \mathrm{n}=12)$ and relative proportions of stevioside, rebaudioside A, rebaudioside $\mathrm{C}$, rebaudioside $\mathrm{D}$, rebaudioside $\mathrm{M}$, and total glycosides for field-grown stevia genotype 10-43-41 across five different daily light integrals (DLI).

\begin{tabular}{ccccccc}
\hline $\begin{array}{l}\text { Mean DLI } \pm \text { SD } \\
\left(\mathrm{mol} \cdot \mathrm{m}^{-2} \cdot \mathrm{d}^{-1}\right)\end{array}$ & Stevioside & Reb A & Reb C & Reb D & Reb M & Total \\
\hline $\begin{array}{l}\text { Concn }(\mathrm{mg} / \mathrm{g}) \\
10.32 \pm 3.03\end{array}$ & $32.75 \mathrm{~b}^{\mathrm{z}}$ & $29.72 \mathrm{a}$ & $5.09 \mathrm{a}$ & $9.77 \mathrm{c}$ & $1.60 \mathrm{a}$ & $78.93 \mathrm{a}$ \\
$11.11 \pm 3.26$ & $32.74 \mathrm{ab}$ & $31.35 \mathrm{a}$ & $5.17 \mathrm{a}$ & $10.10 \mathrm{c}$ & $1.65 \mathrm{a}$ & $84.06 \mathrm{a}$ \\
$17.07 \pm 5.01$ & $32.43 \mathrm{ab}$ & $29.53 \mathrm{a}$ & $5.14 \mathrm{a}$ & $9.34 \mathrm{bc}$ & $1.82 \mathrm{a}$ & $78.25 \mathrm{a}$ \\
$24.21 \pm 7.11$ & $30.31 \mathrm{a}$ & $33.35 \mathrm{a}$ & $5.40 \mathrm{a}$ & $8.00 \mathrm{ab}$ & $1.59 \mathrm{a}$ & $78.65 \mathrm{a}$ \\
$39.70 \pm 11.66$ & $28.64 \mathrm{a}$ & $32.32 \mathrm{a}$ & $5.57 \mathrm{a}$ & $7.63 \mathrm{a}$ & $1.62 \mathrm{a}$ & $75.80 \mathrm{a}$ \\
Relative proportion $(\%$ of total steviol glycosides) & & & & \\
$10.32 \pm 3.03$ & $41.55 \mathrm{~b}$ & $37.57 \mathrm{a}$ & $6.44 \mathrm{ab}$ & $12.42 \mathrm{~b}$ & $2.02 \mathrm{a}$ & \\
$11.11 \pm 3.26$ & $42.37 \mathrm{~b}$ & $37.32 \mathrm{a}$ & $6.18 \mathrm{a}$ & $12.15 \mathrm{~b}$ & $1.97 \mathrm{a}$ & \\
$17.07 \pm 5.01$ & $41.40 \mathrm{~b}$ & $37.76 \mathrm{a}$ & $6.56 \mathrm{bc}$ & $11.96 \mathrm{~b}$ & $2.32 \mathrm{a}$ & \\
$24.21 \pm 7.11$ & $38.55 \mathrm{a}$ & $42.37 \mathrm{~b}$ & $6.88 \mathrm{c}$ & $10.19 \mathrm{a}$ & $2.02 \mathrm{a}$ & \\
$39.70 \pm 11.66$ & $37.71 \mathrm{a}$ & $42.80 \mathrm{~b}$ & $7.37 \mathrm{~d}$ & $9.97 \mathrm{a}$ & $2.15 \mathrm{a}$ & \\
\hline
\end{tabular}

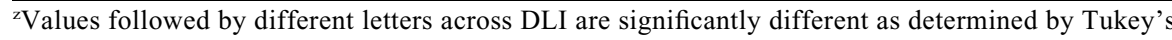
$\operatorname{HSD}_{(0.05)}$

to $1 \mathrm{~h}$ of night-interruption red light produced higher amounts of total steviol glycosides, although the proportions of measured glycosides

remained relatively constant (Ceunen et al., 2012). The authors hypothesized that the phytochrome-mediated responses have an effect on the upstream genes in the steviol glycoside pathway, and not the more downstream UGTs responsible for the glycosylation of steviol. In this study (expt. 1), similar DLIs were created in run 1 and run 2 , averaging 11.87 and $10.50 \mathrm{~mol} \cdot \mathrm{m}^{-2} \cdot \mathrm{d}^{-1}$, respectively. However, the natural DLI during run 2, which was conducted in the fall, was much lower than the natural DLI during the summer months of run 1 . Therefore, supplemental lighting was employed more often in run 2 , especially in the evening and morning hours since the ambient daylength was also shorter. Stevioside concentrations were considerably higher in run $2(18.07 \mathrm{mg} / \mathrm{g})$, compared with run $1(10.88 \mathrm{mg} / \mathrm{g})$. A more thorough understanding of how phytochrome-mediated responses may affect the steviol biosynthesis pathway, or particular components such as stevioside, is needed.

Collectively, these results show that DLI, particularly $<10 \mathrm{~mol} \cdot \mathrm{m}^{-2} \cdot \mathrm{d}^{-1}$, can influence both the concentration and composition of the steviol glycoside pool. The relative proportion of a particular glycoside is important as it can influence extraction and purification efficiency. This study has also shown that, although the general response by stevia genotypes to DLI may be similar, the degree of response can vary by genotype. Stevia rebaudiana possesses considerable genetic variability due to high rates of outcrossing (Heikal et al., 2008; Singh et al., 2008). Therefore, more genotypes or populations should be evaluated in describe the degree of variability in stevia responses to DLI under long photoperiods.

\section{Literature Cited}

Ballare, C.L. and A.L. Scopel. 1994. Plant photomorphogenesis and canopy growth, p. 89-102. In: T.W. Tibbitts (ed.). International lighting in controlled environments workshop, NASACP-95-3309.

Brandle, J.E. and N. Rosa. 1992. Heritability for yield, leaf:stem ratio and stevioside content estimated from a landrace cultivar of Stevia rebaudiana. Can. J. Plant Sci. 72:1263-1266.

Brandle, J.E. and P.G. Telmer. 2007. Steviol glycoside biosynthesis. Phytochemistry 68:1855-1863.

Ceunen, S. and J.M.C. Geuns. 2013a. Steviol glycosides: Chemical diversity, metabolism, and function. J. Nat. Prod. 76:1201-1228.

Ceunen, S. and J.M.C. Geuns. 2013b. Influence of photoperiodism on the spatio-temporal accumulation of steviol glycosides in Stevia rebaudiana (Bertoni). Plant Sci. 198:72-82.

Ceunen, S., S. Werbrouck, and J.M.C. Geuns. 2012. Stimulation of steviol glycoside accumulation in Stevia rebaudiana by red LED light. J. Plant Physiol. 169:749-752.

Ermakov, Y. and A.A. Kochetov. 1996. Specificities of the growth and development of stevia plants under different controllable light conditions. Russ. Agr. Sci. 1:9-11.

Franklin, K.A. and P.H. Quail. 2010. Phytochrome functions in Arabidopsis development. J. Expt. Bot. 61:11-24.

Guleria, P., V. Kumar, and S. Yadav. 2011. Effect of sucrose on steviol glycoside biosynthesis pathway in Stevia rebaudiana. Asian J. Plant Sci. 10:401-407.

Heikal, A., O. Badawy, and A. Hafez. 2008. Genetic relationships among some Stevia 
(Stevia rebaudiana Bertoni) accessions based on ISSR analysis. Res. J. Cell and Mol. Biol. 2:1-5.

Kennelly, E.A. 2002. Sweet and non-sweet constituents of Stevia rebaudiana, p. 68-85. In: A.D. Kinghorn (ed.). Stevia: The genus Stevia. Taylor \& Francis, Inc., New York, NY.

Kinghorn, A.D., D.D. Soejarto, N.P. Nanayakkara, C.M. Compadre, H.C. Makapugay, J.M. HovanecBrown, P.J. Medon, and S.K. Kamath. 1984. A phytochemical screening procedure for sweet ent-kaurene glycosides in the genus Stevia. J. Nat. Prod. 47:439-444.

Kumar, R., S. Sharma, K. Ramesh, and B. Singh. 2013. Effects of shade regimes and planting geometry on growth, yield and quality of the natural sweetener plant stevia (Stevia rebaudiana Bertoni) in north-western Himalaya. Arch. Agron. Soil Sci. 59:963-979.

Metivier, J. and A. Viana. 1979. The effect of long and short day length upon the growth of whole plants and the level of soluble proteins, sugars, and stevioside in leaves of Stevia rebaudiana. J. Expt. Bot. 30:1211-1222.
Mohamed, A.A.A., S. Ceunen, J.M.C. Geuns, W. Van den Ende, and M. De Ley. 2011. UDP-dependent glycosyltransferases involved in the biosynthesis of steviol glycosides. J. Plant Physiol. 168:1136-1141.

Ohtani, K., Y. Aikawa, R. Kasai, and W. Chou. 1992. Minor diterpene glycosides from sweet leaves of Rubus suavissimus. Phytochemistry 31:1553-1559.

Park, Y.G., H.J. Oh, and B.R. Jeong. 2013. Growth and anthocyanin concentration of Perilla frutescens var. acuta Kudo as affected by light source and DIF under controlled environment. Hort. Environ. and Biotechnol. 54:103-108.

Richman, A., A. Swanson, T. Humphrey, R. Chapman, B. McGarvey, R. Pocs, and J. Brandle. 2005. Functional genomics uncovers three glucosyltransferases involved in the synthesis of the major sweet glucosides of Stevia rebaudiana. Plant J. 41:56-67.

Shafii, B., R. Vismen, R. Beaudry, R. Warner, and A. S. Jones. 2012. Large-scale profiling of diterpenoid glycosides from Stevia rebaudiana using ultrahigh performance liquid chromatography/ tandem mass spectrometry. Anal. Biol. Chem. 403:2683-2690.

Shock, C. 1982. Rebaudi's stevia: Natural noncaloric sweetners. Calif. Agr. 36(9-10):4-5.

Singh, H.P., S. Dhir, and S.K. Dhir. 2008. Stevia, p. 97-115. In: C. Kole and T. Hall (eds.). Compendium of transgenic crop plants: Transgenic sugar, tuber and fiber crops. Blackwell Publishing Ltd., Boston, MA.

Valio, I.F.M. and R.F. Rocha. 1977. Effect of photoperiod and growth regulator on growth and flowering of Stevia rebaudiana Bertoni. Jpn. J. Crop. Sci. 46:243-248.

Zaidan, L., S. Dietrich, and G. Felippe. 1980. Effect of photoperiod on flowering and stevioside content in plants of Stevia rebaudiana Bertoni. Jpn. J. Crop. Sci. 49: 569-574.

Zhou, X., C. Liang, Q. Xu, X. Zhang, and X. Liang. 2012. Study on chemical constituemts of Angelica keiskei. Chin. J., Exp. Trad. Med. Form. 18(3):103-105. 